УДК 619:618.19-006:616.071:636.8

(C) 2013

Виговська К. Л., аспірант *

Луганський національний аграрний університет

\title{
ДИФЕРЕНЦЙНА ДІАГНОСТИКА ПУХЛИН МОЛОЧНИХ ЗАЛОЗ У КІШОК
}

\section{Рецензент - кандидат ветеринарних наук В. М. Симонович}

Наведені дані, отримані в результаті клінікогістологічних досліджень пухлин молочних залоз кішок. У досліджені брали участь 79 тварин віком від семи місяиів до вісімнадиятти років, які поступали на прийом із приводу новоутворень молочної залози. Гістологічні дослідження пухлин молочної залози підтвердили діагноз: доброякісні пухлини: 10 - фіброаденоматози, 4 - кістози, 6-аденоматози, 7 - змішаної будови, 52 злоякісні пухлини (аденокарциноми). 3-поміж злоякісних пухлин виділено зразки інфільтруючого та неінфільтруючого раку, що має тубулярну, папілярну або солідну структуру. Гістологічні дослідження дають можливість прогнозувати перебіг захворювання, а у випадку злоякісних пухлин планувати адекватні лікувальні прийоми для збереження здоров'я тварин або для поліпшення якості їх життя.

Ключові слова: кішка, пухлини, гістологічне дослідження.

Постановка проблеми. У сучасних умовах велике значення має обслуговування і лікування дрібних домашніх тварин. Серед гінекологічних проблем кішок зустрічаються захворювання молочних залоз, у тому числі мастопатії та злоякісні пухлини. Диференціальна діагностика різних форм доброякісних процесів і раку молочних залоз у деяких випадках буває вкрай складною через те, що багато доброякісних процесів схильні до малігнізації, а ранні стадії раку й деякі його форми залишаються тривалий час інкапсульованими, нагадуючи доброякісний ріст $[4,6]$. Завдання ветеринарних фахівців - вчасно поставити діагноз і зробити правильний прогноз розвитку хвороби та їі перебігу.

Аналіз основних досліджень і публікацій, у яких започатковано розв'язання проблеми. Молочні залози у тварин розвиваються з ектодерми і за своєю природою є зміненими потовими залозами шкіри. 3 початку статевого дозрівання ця екзокринна залоза являє собою термінальні протоково-долькові одиниці, що сходяться до соска. Відділи залози вистилають два шари клітин: епітеліальні і міоепітеліальні, а вивідні протоки в області соска вистилає багатошаровий плоский епітелій $[4,1]$.

Джерелом розвитку пухлин молочних залоз вважають елементи дольки 3 внутрішньодольковою стромою і міждолькові протоки. У формуванні дисгормональних проліфератів, доброякісних і злоякісних пухлин беруть участь клітини секреторного епітелію, міоепітелій, елементи сполучної тканини, плоский епітелій протоків сосків. Встановлено, що рак виникає 3 камбіальних клітин або їх попередників, що здатні до мітотичної активності, а не із зрілих диференційованих клітин $[2,3]$.

Понад 80 \% пухлин молочної залози гістологічно класифікуються як аденокарциноми. Зі специфічних видів аденокарцином частіше зустрічаються тубулярні, папілярні та солідні карциноми, а саркоми, слизові карциноми, протокові папіломи, аденосквамозні карциноми й аденоми зустрічаються рідко. Більшість аденокарцином складаються з комбінації різних видів тканин $[5,7]$.

Мета досліджень. Метою нашої роботи було проведення диференційної діагностики пухлин молочних залоз у кішок на основі гістологічного методу.

Методика проведення досліджень. На хворих тварин заводили історію хвороби, збирали детальний анамнез, після чого проводили клінічне обстеження. За виявлення видимої пухлини визначали іï локалізацію, форму, розмір, характер росту, консистенцію, рухливість відносно навколишніх тканин, наявність супутнього запалення, стан регіональних лімфатичних вузлів. Для виявлення метастазів у черевній порожнині використовували ультразвукове дослідження. Всього досліджено 79 кішок віком від 7-ми місяців до 18-ти років. Отриманий під час мастектомії матеріал фіксували в $10 \%$-у водному розчині нейтрального формаліну. Гістологічні дослідження проводили в лабораторії онкологічного диспансеру міста Луганська за методом фіксованих і фарбованих постійних препаратів.

* Науковий керівник - кандидат сільськогосподарських наук В. С. Кот 
Результати досліджень. За загального клінічного обстеження кішок вузловий характер пухлинного зростання виявлений у 92,4 \% кішок, у 7,6\% кішок відмічено дифузне зростання. У $67 \%$ кішок спостерігалися одиничні новоутворення, первинно-множинний процес - у $32,9 \%$ кішок. Діаметр найбільшого пухлинного вузла менше 1 см відмічений у 6,3\% кішок, від 1 до $3 \mathrm{~cm}$ - у 55,7 \% кішок, більше $3 \mathrm{~cm}$ - у $38 \%$ кішок. Кістозні порожнини в пухлинах при пальпації виявлені у 13,9 \% кішок, виразковий дефект спостерігався в $12,7 \%$ випадках. Ознаки малігнізації регіонарних лімфатичних вузлів при пальпації у кішок 3 пухлинами молочних залоз були відмічені в $31,6 \%$ випадків. У результаті комплексного обстеження тварин, які поступили в клініку на первинний прийом, у $70 \%$ випадків був поставлений попередній діагноз: рак молочних залоз. У прооперованих кішок при морфологічній верифікації діагноз рак молочних залоз був підтверджений у $66 \%$ кішки, а у $4 \%$ кішок рак не підтверджено. Діагноз метастатичний рак у всіх випадках був поставлений на підставі ультразвукового дослідження.

Клінічно виявлені злоякісні пухлини зазвичай знаходяться в стані прогресуючого розвитку. Новоутворення щільні й вузлуваті, зрощені з довколишньою шкірою на нижній частині черевної стінки (аденокарциноми і фіброаденоми). Чверть уражених тварин має покриту виразками пухлину, соски почервонілі й набряклі, виділяють рудувато-коричневу або жовту рідину. Пухлина вражає кілька або всі молочні залози як із лівого, так і з правого боку. Кістозна гіперплазія виглядає як одна або декілька збільшених часток із розширеним протоковим компонентом, досягаючи великих розмірів, а при аспірації виділяється прозора або жовтувата рідина.
За результатами гістологічних досліджень виявлено: 10 - фіброаденоматози, 4 - кістози, 6 - аденоматози, 7 - змішаної будови та 52 злоякісні пухлини (аденокарциноми).

Аденома (від грец. aden - залоза) - зріла доброякісна пухлина із залозистого епітелію. Аденома має органоїдну будову, паренхіма складається з клітин призматичного або кубічного епітелію. Епітелій зберігає комплексність і полярність, розміщений на власній мембрані й формує залозисті структури. Залозисті структури оточені волокнистою сполучною тканиною, в якій розміщені судини (рис. 1).

Прості, тубулярні аденоми в молочній залозі зустрічаються рідко. Найчастішою пухлиною молочних залоз є фіброаденома. У фіброаденомі виражений тканинний атипізм: залози не будують часточок, вони різного діаметра й форми. Строма представлена щільною волокнистою сполучною тканиною з невеликою кількістю щілинних судин.

У будові пухлин десяти кішок переважав залозистий компонент. Деструкція молочної залози виражена у випадку склеротизуючого аденозу (рис. 2). Для цієї форми дисплазії характерні зміни у фіброзній тканині довкола часточок, окрім того $\epsilon$ проліферація залозистого компонента протоків, іноді до повної їх облітерації.

Аденокарцинома - незріла злоякісна пухлина 3 призматичного епітелію, яка формує залозисті структури різної форми й величини, що вростають у навколишні тканини і руйнують їх. На відміну від аденоми, різко виражений клітинний атипізм, який проявляється поліморфізмом клітин, гіперхромією ядер. Базальна мембрана епітеліальних клітин зруйнована. Залози можуть бути сформовані багаторядним епітелієм, однак просвіт їх завжди збережений.

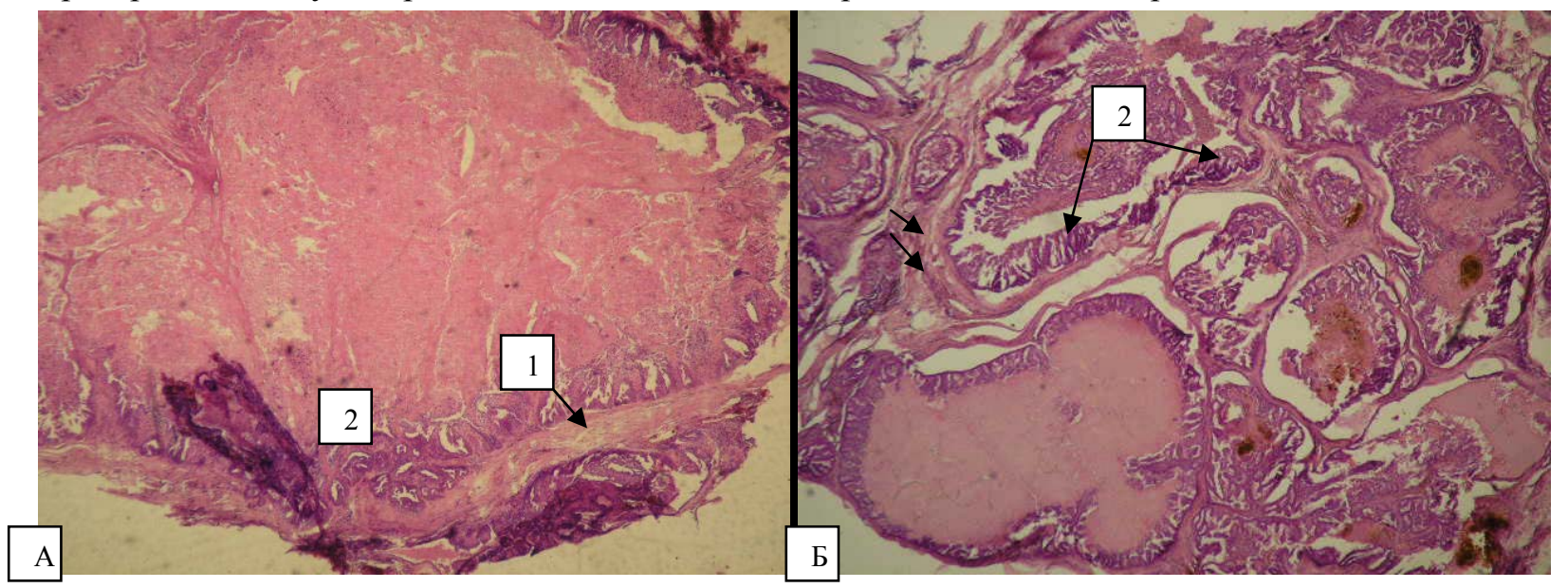

Рис. 1. Фрагмент аденоми молочної залози кішки. Гематоксилін і еозин, х 100.

Сполучнотканинна капсула (1), від якої відходить епітеліальна тканина (2). 

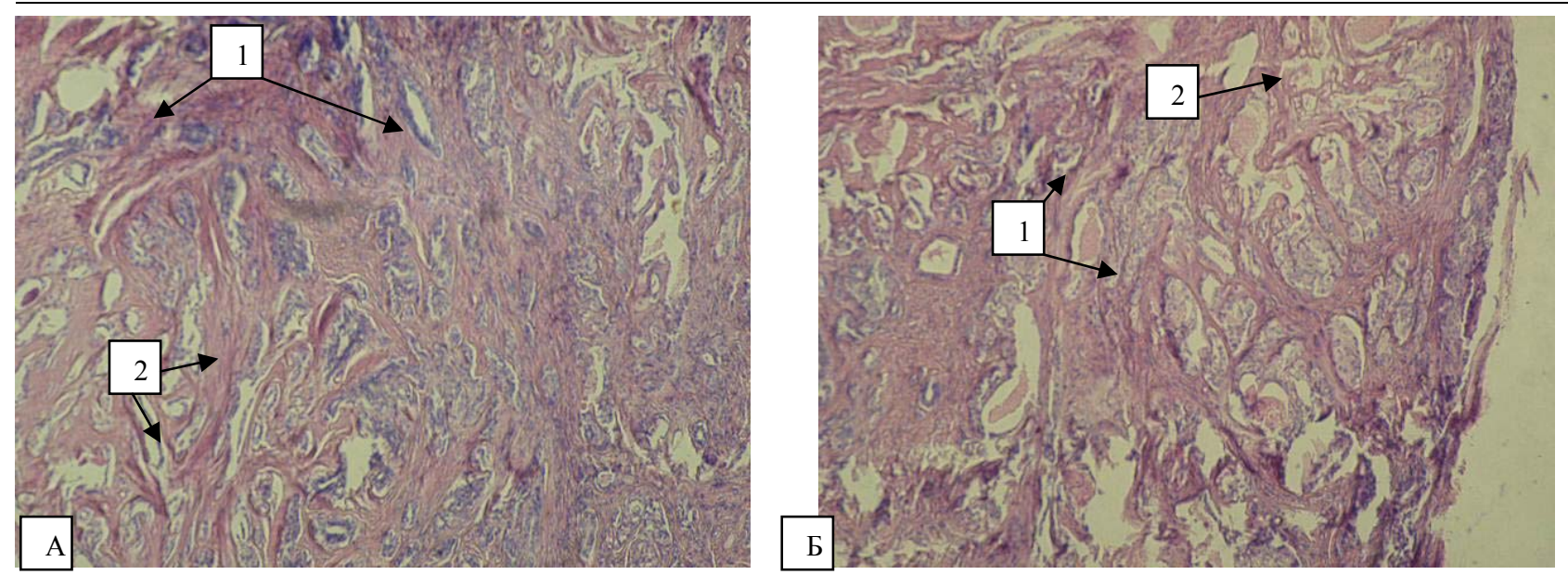

Рис. 2. Фрагмент пухлини молочної залози кішки. Склеротизуючий аденоз.

Гематоксилін і еозин, х 160. Виражений фіброзний компонент (1), часточки зменшені (2).

Інколи просвіт залоз розширений і в них $є$ сосочкові випинання - це сосочкова, або папілярна аденокарцинома (рис. 3).

Аденокарцинома має різний ступінь диференціювання, що може визначати ії клінічний перебіг і прогноз. У однієї кішки була діагностована тубулярна карцинома простого типу, що складалася 3 трубочок різних розмірів неправильної форми 3 вираженими просвітами, які вистилає одно- та двошаровий поліморфний епітелій (рис. 4).

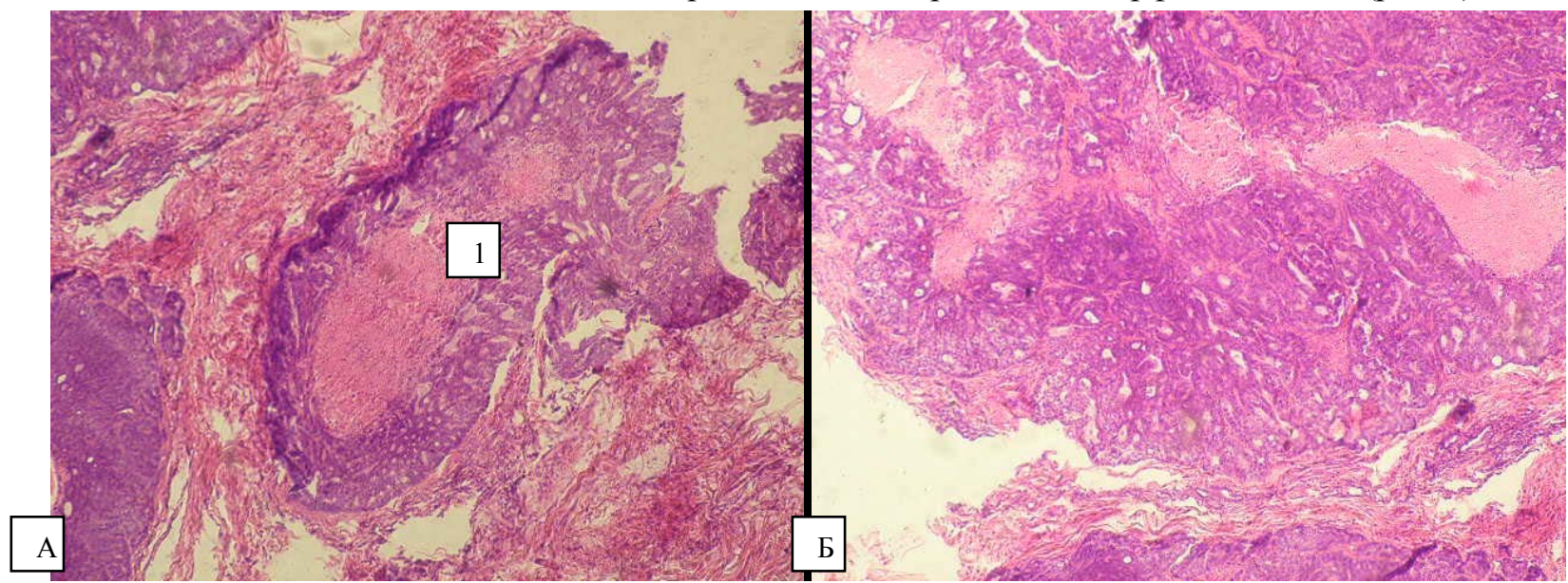

Рис. 3. Фрагмент папілярної аденокарциноми молочної залози кішки.

Гематоксилін і еозин, х 160. Папілярні структури (1), побудовані з епітеліальної тканини.

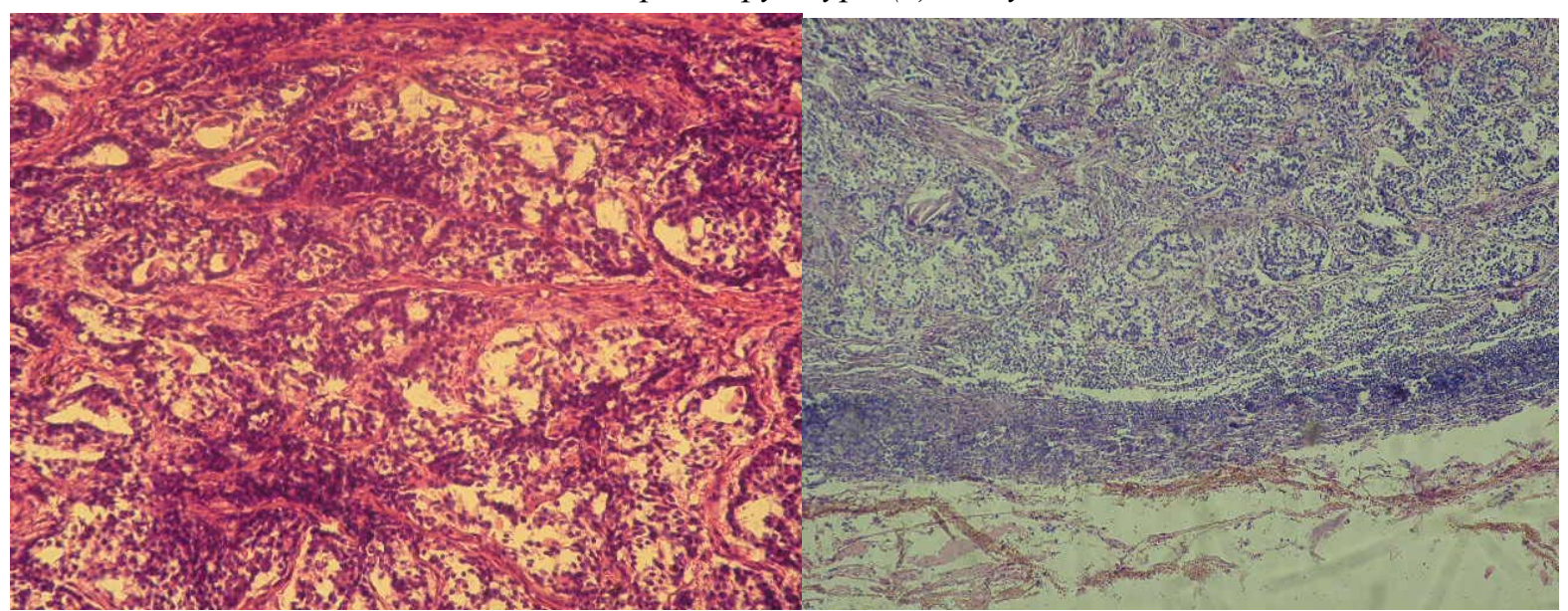

Рис. 4. Фрагмент тубулярної аденокарциноми молочної залози кішки. Гематоксилін і еозин, х 160.
Рис. 5. Фрагмент інфільтруючого лобулярного раку молочної залози кішки. Гематоксилін і еозин, х 160. 


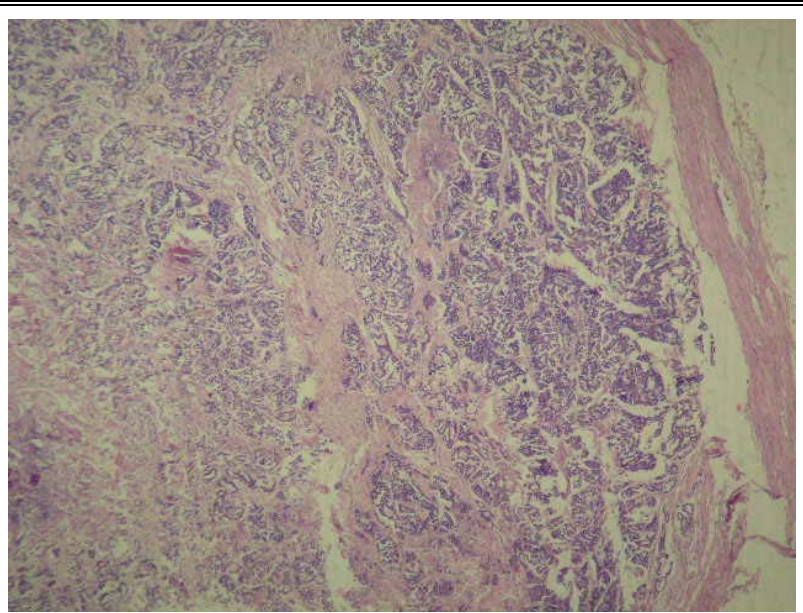

Рис. 6. Фрагмент інфільтруючого лобулярного раку молочної залози кішки. Гематоксилін і еози, х 100.

$\mathrm{y}$ залежності від місця виникнення рак молочної залози поділяють на дольковий (рис. 6,7 )

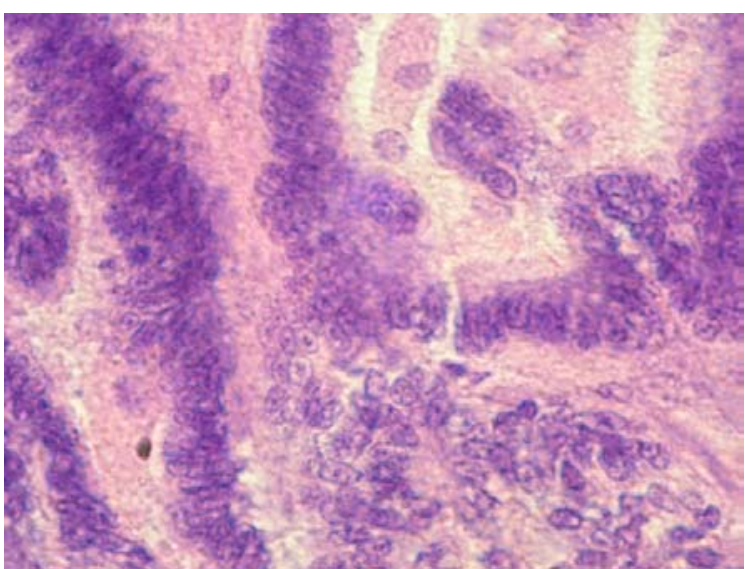

Рис. 7. Фрагмент протокового раку молочної залози кішки.

Гематоксилін і еозин, х 400. і протоковий (рис. 8, 9). Дольковий рак складається із солідних ділянок, що мають тенденцію до формування дольок. За протокового раку строма залози збережена у вигляді окремих волокон. Структура раку повторює структуру протоків молочної залози.

Гістологічно рак поділяють на інфільтруючий і неінфільтруючий (рис. 9). У зразках неінфільтруючого раку атипові клітини заповнюють просвіти дольок.

Солідний рак (від лат. solidum - щільний) (рис. 10, 11) - це форма залозистого недиференційованого раку. Мікроскопічно відрізняється від аденокарциноми тим, що в псевдозалозистих комплексах будуть відсутні просвіти, заповнені проліферуючими пухлинними клітинами. Виражений клітинний і тканинний атипізм. У клітинах пухлини мали місце досить часті мітози.

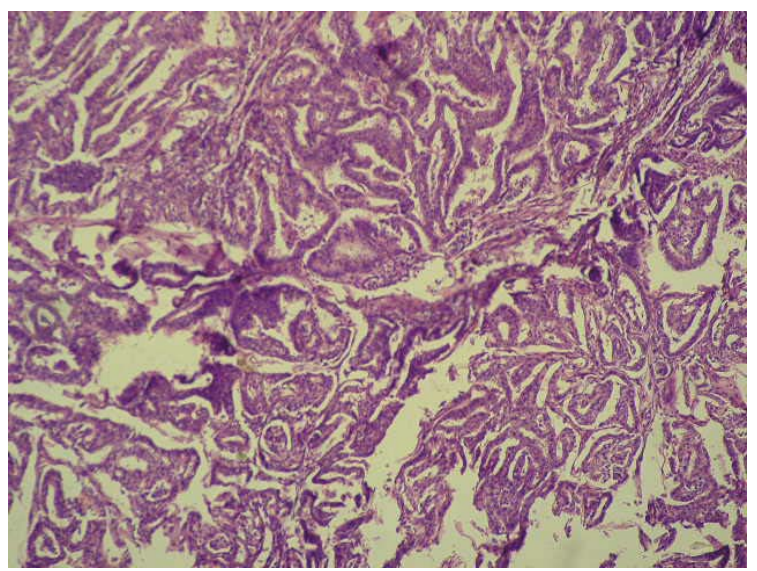

Рис. 8. Фрагмент протокового раку молочної залози кішки.

Гематоксилін і еозин, х 160.

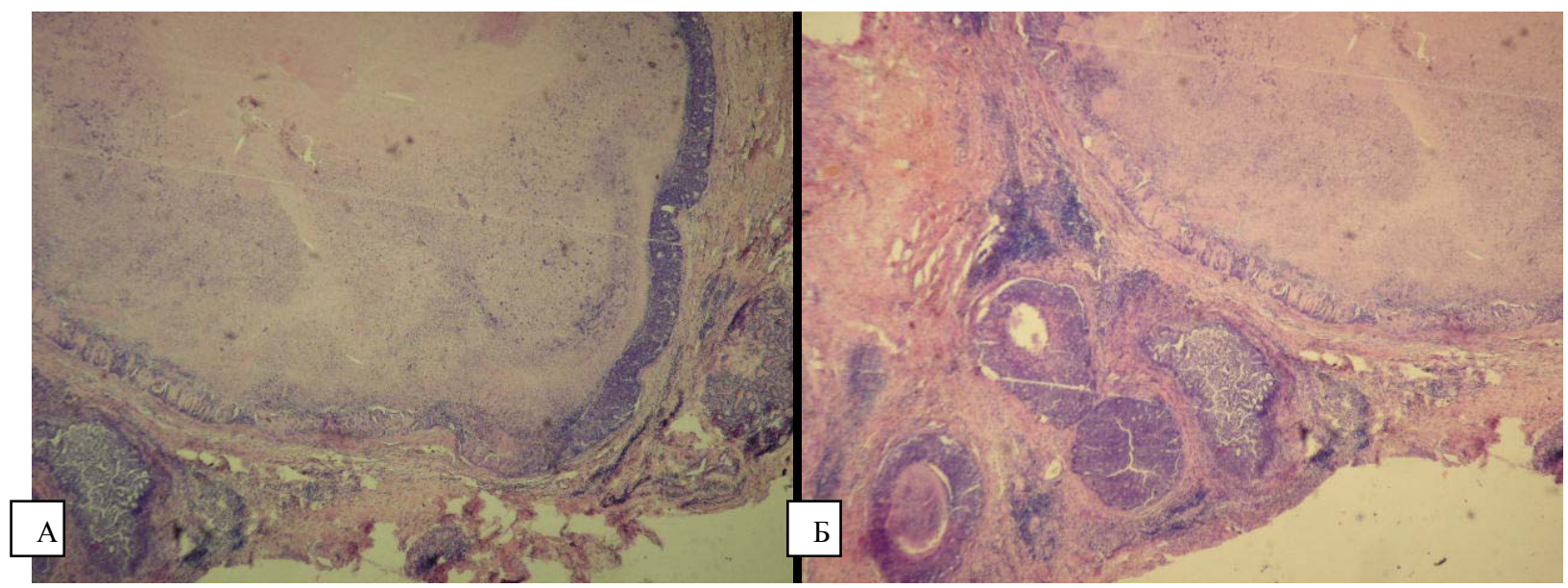

Рис. 9. Фрагмент неінфільтруючого раку молочної залози кішки іп situ.

Гематоксилін і еозин, х 160. 


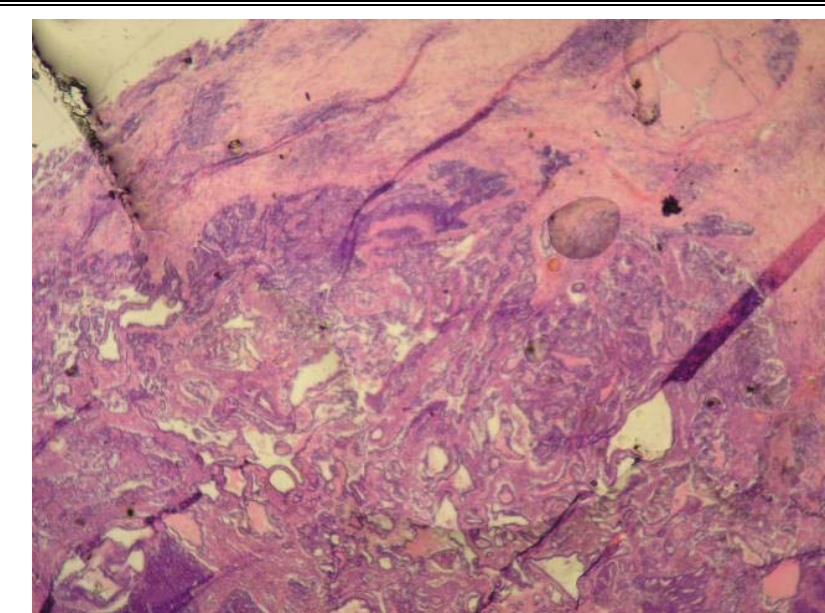

Рис. 10. Фрагмент інфільтруючого раку молочної залози кріброзно-солідного типу. Гематоксилін і еозин, х 100.

Фрагмент інфільтруючого раку молочної залози кріброзно-солідного типу має вигляд протокової карциноми з внутріпротоковими структурами у вигляді решітки.

\section{Висновки:}

1. Гістологічні дослідження пухлин молочної залози підтвердили діагноз доброякісні пухлини: 10 - фіброаденоматози, 4 - кістози, 6 - аденоматози, 7 - змішаної будови та 52 злоякісні пухлини (аденокарциноми).

2. 3-поміж злоякісних пухлин виділено зразки

\section{БІБЛІОГРАФІЯ}

1. Дюльгер Г. П. Физиология размножения и репродуктивная патология собак / Г. П. Дюльгер. М. : Колос, 2002. -152 c.

2. Онкологія: Підручник. - 3-тє видання, перероб. і доп. / Б. Т. Білинський, Н. А. Володько, А. І. Гнатишак [та ін.]; За ред. проф. Б. Т. Білинського. - К. : Здоров'я, 2004. - 528 с.

3. Рак молочной железы : учебное пособие / Е. П. Куликов, Б. М. Варенов. - Рязань: Рязань, 2002. $-75 \mathrm{c}$.

4. Якунина М. Н. Рак молочной железы у собак и кошек. / М. Н. Якунина, В. А. Голубева, Д. В. Гаранин. - М. : Зоомедлит, Колос С, 2010. - 79 с.

5. Canine Mammary Carcinoma /Allison McCarthy; Perry J. Bain; Kenneth S. Latimer [Electronic re-

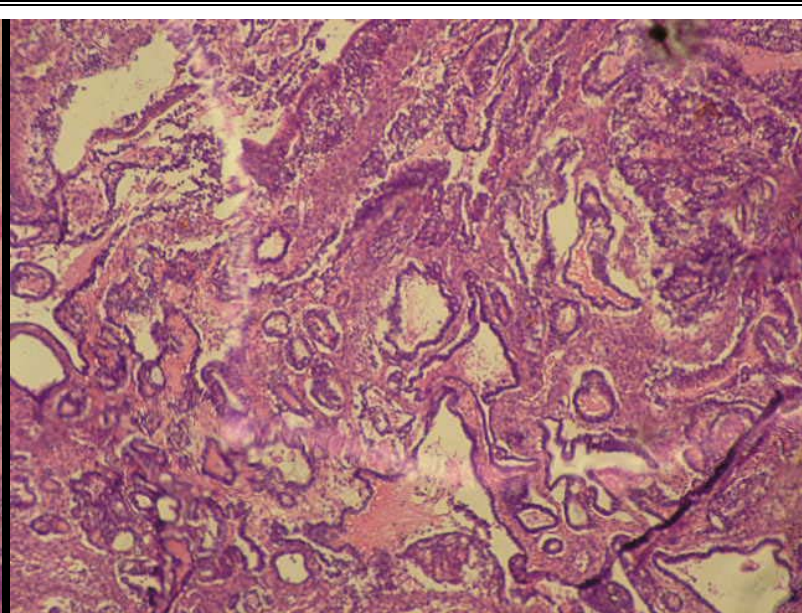

Рис. 11. Фрагмент інфільтруючого раку молочної залози кріброзно-солідного типу. Гематоксилін і еозин, х 160.

інфільтруючого та неінфільтруючого раку, що має тубулярну, папілярну або солідну структуру.

3. Ранні стадії раку та деякі його форми залишаються тривалий час інкапсульованими, нагадуючи доброякісний ріст.

4. Гістологічні дослідження дають можливість прогнозувати перебіг захворювання, а у випадку злоякісних пухлин - планувати адекватні лікувальні прийоми для збереження здоров'я тварин або для поліпшення якості їх життя.

source] // Class of 2003 (McCarthy) and Department of Pathology (Bain, Latimer), College of Veterinary Medicine, The University of Georgia, Athens, GA 30602-7388. - Electronic data. - Mode of access: http://aleksabokarev.narod.ru/foreignarticle2/6.pdf. - Title from the screen.

6. Gregory K. Ogilvie. Ten Best Kept Secrets for Treating Cats with Cancer [Electronic resource] / K. Gregory CO USA WSAWA 2002 - Electronic data. Mode of access: http://www.vin.com/proceedings/Proceedings.plx?CID=WSAVA2002\&PID $=2636$.

7. Hayes A. A., Mooney S. T. Feline mammary tumours // Vet Clin North Am Small Anim Pract. 1985. - V. 15. - P. 513-520. 